\title{
Analysis of the Perception of Quality in Service in a Higher Education Institution with the use of the ModelServQual
}

\section{Análisis de la Percepción de la Calidad en el Servicio en una Institución de Educación Superior con el uso del Modelo ServQual}

\author{
LIMON-VALENCIA, Luis Alberto $\dagger^{*}$, GRIJALVA-TAPIA, Juan, RUIZ-CASTRO, Manuela and \\ HINOJOSA-TAOMORI, Karina Alejandra
}

Instituto Tecnológico Superior de Cajeme

ID $1^{\text {st }}$ Author: Luis Alberto, Limon-Valencia / ORC ID: 0000-0002-9533-602X

ID $1^{\text {st }}$ Coauthor: Juan, Grijalva-Tapia / ORC ID: 0000-0003-4028-555X

ID $2^{\text {nd }}$ Coauthor: Manuela, Ruiz-Castro / ORC ID: 0000-0002-9664-9546

ID $3^{\text {rd }}$ Coauthor: Karina Alejandra, Hinojosa-Taomori / ORC ID: 0000-0003-4118-118

DOI: $10.35429 / J M Q M .2019 .5 .3 .9 .17$

Received July 28, 2019; Accepted November 10, 2019

\begin{abstract}
The main objective is to evaluate the quality of the service; likewise, to determine what are the essential aspects and measure the quality of service from the students. As expressed by Duque and Chaparro (2012), it is not recommended that the evaluation of the quality of the service only considers the point of view of executives and government agencies, since the perception of the most important client, the student, would be evaded. The method to follow is to determine the variables that will be studied and we establish the instrument to collect information, determine the population to which the study is directed, apply the instrument to the sample, present the results obtained, draw conclusions comparing it with the theoretical framework and with other studies; and finally, the recommendations of the findings. Among the main findings, it was possible to obtain the qualification of the service quality of the students in the period evaluated, the overall score reached is 5.18, interpreted as good service and representing $74 \%$. It is relevant to consider that the characteristic with lower qualification, in this case, the appearance of physical facilities, equipment, personnel and communication material.
\end{abstract}

Quality, Service, ServQual

\begin{abstract}
Resumen
El objetivo principal es evaluar la calidad del servicio; así mismo determinar cuáles son los aspectos más importantes y medir la calidad de servicio desde el punto de vista de los estudiantes. Como lo expresan Duque y Chaparro (2012), no es recomendable que la evaluación de la calidad del servicio solo considere el punto de vistas de directivos y organismos gubernamentales, ya que se estaría evadiendo la percepción del cliente más importante, el alumno. El método a seguir es determinar las variables que se estudiarán y se establece el instrumento para recolectar información, determinar la población a la cual se dirige el estudio, aplicar el instrumento a la muestra, presentar los resultados obtenidos, elaborar conclusiones comparándola con el marco teórico y con otros estudios; y por último se realizan las recomendaciones de los hallazgos. Entre los hallazgos principales se pudo obtener la calificación de la calidad del servicio de los estudiantes en el período evaluado, la puntuación general alcanzada es 5.18, interpretada como buen servicio y que representa un $74 \%$. Es relevante tomar en cuenta que la característica con menor calificación, en esta caso, la apariencia de las instalaciones físicas, equipo, personal y material de comunicación.
\end{abstract}

Calidad, Servicio, ServQual

Citation: LIMON-VALENCIA, Luis Alberto, GRIJALVA-TAPIA, Juan, RUIZ-CASTRO, Manuela and HINOJOSATAOMORI, Karina Alejandra. Analysis of the Perception of Quality in Service in a Higher Education Institution with the use of the ModelServQual. Journal-Mathematical and Quantitative Methods. 2019. 3-5: 9-17

$\dagger$ Researcher contributing first author 


\section{Introduction}

Education is considered one of the most important tools for the development of humanity. According to the United Nations Educational, Scientific and Cultural Organization (UNESCO, 2017), education is a right of every person and that education must be of quality. And referring to educational quality, Edwards (1991), defines it as a judgment fixed to an educational product from the comparative point of view; it compares the observed reality with a desirable term. He adds that, to improve educational quality, it is necessary to use an approach from the point of view of the subject, that is, of the one who learns, the student.

The Mexican government, taking into account the need to achieve comprehensive development of the country, through the General Directorate of Higher Technological Education (DGEST, 2017), took on the task, in 2012, of updating the processes, plans and programs of study for the training of professionals, creating for this purpose, the Educational Model for the 21st Century: Training and Development of Professional Skills. In this document, it is specified that within its main guidelines, it is to increase the quality of educational services of the institutions of the National System of Technological Institutes.

Duque and Edison (2005) indicate that due to the characteristic of the intangibility of the services, their quality is measured, in many circumstances, subjectively. In their work, they define service quality as the difference between consumer expectations and their perception of the result. Also, Torres and Vásquez (2015), indicate that the common attributes of different methods of evaluating service quality are: tangible aspects, user care and service reliability. Service quality should be defined by the attributes that the customer expects from the service and by the amount he is willing to pay for that service. This is similar to the quality of physical products, where the attributes are easier to quantify.

As indicated by Reyes and Reyes (2012), the evaluation of the quality of the educational service at the higher level is carried out by different means: teacher evaluation, accreditation of degree programs, suggestion box, among others.
They add that the evaluation of the quality of the service in these institutions is of great importance, to have control of the processes and thus be able to improve their operation. They also describe that a tactic to increase the quality of the educational service is to satisfy the expectations of the students, making reference to the process that a company carries out to fulfil the expectations that its clients have.

In a study by Duque and Chaparro, they admit that an assessment of educational quality in a higher-level institution that does not consider the student's perception is to ignore the importance of the role played by the student in the process of continuous improvement (as quoted in Duque \& Gómez, 2014, p. 183).

The coordination of the career under study states that according to interviews with their two predecessors in the position, which in sum cover ten years, no study has been conducted to find out what aspects students consider important when making a judgment on the quality of the service they receive from the institution.

This leads to the following questions addressed in this investigation: What are the dimensions that students in the Industrial Engineering career consider most important when evaluating the quality of the service they receive?

Considering the problem posed and the questions that this research seeks to answer, the general objective is to evaluate the quality of the service from the point of view of the students of an educational program. Looking for with this: First, to determine which are the most critical aspects, about the quality of service and to measure the quality of service that they perceive. The present study was carried out only on the students of an educational program. It will be limited to knowing the perceptions of those students about the service they offer using the SERVQUAL instrument. The study does not intend to develop, implement or test strategies to improve the quality of the educational service.

This article presents an analysis of the most important theoretical elements and foundations, the method of the work as well as in the analysis of the results obtained. 


\section{Overview of services}

Services have become an essential product in the economy of most societies. According to the World Trade Organization (WTO), the rapid growth of the service sector makes it the generator of two-thirds of world output, which in turn generates one-third of employment. (World Trade Organization, 2017)

As explained by Lovelock, Reynoso, D'Andrea and Huete, (2004), it is crucial for managers to know the series of steps involved in producing a service, since clients regularly participate in generating it. Fernández and Bajac (2003) state that for a service to provide a valuable experience for the consumer, it must be correctly designed in all its components, among which they mention the operating processes. Just like the process of transforming raw materials into a finished product, the process into a service is equally or more relevant, since, in many situations, the same client participates in that process.

To visualize more broadly the types of processes of a service, Lovelock, Reynoso, D'Andrea and Huete, (2004), divide the processes in four categories: tangible acts directed to the body of people; tangible actions guided to their physical possessions; intangible actions directed to the minds of people and intangible acts focused on their intangible assets.

\section{Service quality models}

The Spanish Association for Quality (2017) defines quality models as the source or reference applied by companies to improve their results; they are guidelines that guide, they are not standards to be met. In Duque's opinion (2005), when the concepts of quality are examined, two critical branches can be identified: objective quality and subjective quality, the former being oriented to the producer's perspective and the latter to the consumer's perspective. It is this customer perspective that generates a series of models focused on the evaluation of service quality, in which the customer's point of view is what defines the quality of the service. Duque (2005) describes that the most widely cited measurement models that have emerged from this differentiation between product quality and service quality are the following:
The model of the image of Grönroos recognized as the Nordic school; the SERVQUAL model of Parasuraman, Zeithaml and Berry known as the American school, also clarifying that up to now it is the most used for academic studies; the model of the three components of Rust and Oliver based on what Grönroos proposed and the SERVPERF model of Cronin and Taylor in which they formulated a more detailed scale than SERVQUAL and named it SERVPERF.

\section{Image model or duvet.}

According to Torres and Vásquez (2015), Christian Grönroos, who is the founder of the school of service management and marketing thought, commonly known as the Nordic School of Marketing, proposes a model of service quality that is composed of three elements: the first, technical quality, which explains the "what" of the service received by the customer, represents the objective characteristic. The second, functional quality, represents "how" the customer obtains and experiences the service, which describes how the service has been delivered. And finally, the corporate image indicates the result of how the customer perceives the organization for the service it provides.

\section{Model of the three components}

As described by Vargas and Aldana (2006), the three-component model presented by Roland Rust and Richard Oliver in 1994 is based on the Nordic school proposal and is composed of three elements: first, the service and its characterization; second, the delivery process; and third, the environment surrounding the service. Similarly, Duque (2005), explains that the service and characterization, should be considered the design of the service before being delivered to the end-user, the specifications of that design are based on the target market, i.e. customer expectations. Therefore, in this first element, the importance of knowing, on the part of the service producer, the parameters that the final consumer expects is highlighted. The second element of this model is the delivery process and Vargas and Aldana (2006), emphasize that special care must be taken in the requirements that the client has established for the key moment of the reception of the service, where Grönroos (1994), describes it as the moment of truth. 
And finally, the third element, which refers to the environment where the service is developed, Vargas and Aldana (2006), comment on the existence of two perspectives, the internal and the external one. The first points to the environment within the organization where the service is designed, i.e. the structure of the entity; and the external one refers to the way in which the customer looks at the producer of the service, such as its facilities and its prestige in the field.

\section{SERVPERF model}

The SERVPERF model, derived from the term Service Performance, is described by Torres and Vásquez (2015), as an alternative model to the SERVQUAL model. Cronin and Taylor developed it in 1992 and proposed to evaluate the quality of service based solely on the client's perception. On the same model, Vargas and Aldana (2006), add that its creators use the same 22 statements of the SERVQUAL model related to the five dimensions such as tangibility, reliability, responsiveness, security and empathy.

They further explain that this model also uses the seven-point Likert scale, where they assign one to the statement that is in total disagreement with the customer's perception and seven to the statement that is in total agreement.

Torres and Vásquez (2015) confirm that the SERVPERF model eliminates the use of customer expectations when evaluating service quality. They explain that this is because there is not enough evidence to confirm that the user uses the expectation as a reference point and also because of the tendency of users to exaggerate expectations.

\section{Generalities of the SERVQUAL service quality model}

Concerning customer expectations of service, and according to the SERVQUAL model, Matsumoto (2014) defines expectation as the belief in the reception of the service and adds that expectation is used as the point of comparison to evaluate service quality. Also, Matsumoto (2014), summarizes it in a straightforward phrase: "what the customer expects from a service" (p. 185).
Zeithaml, Parasuraman, and Berry (1990) add that four factors can influence the expectations of service customers: first, the opinions of the people who form their influence group; second, the individual needs of the customers themselves; third, the experiences they have had with the service; and finally, the communication they receive from the service producers themselves.

As indicated by Zeithaml and Bitner (2002), perception in the SERVQUAL model is the action of how the client values the service at the time of receiving it. Similarly, Brady and Cronin Jr. (2001), explain that perception is made at the moment the service is delivered. Thus, perception for the SERVQUAL model is the appreciation of the qualities that the customer gives to the service received. On the other hand, the SERVQUAL model developed by Zeithaml, Parasuraman and Berry (1990), deduces that there are five criteria or dimensions on which customers perceive the service and defines them as follows: One, tangible elements, are the physical aspects of the service producer, such as equipment and infrastructure; two, reliability, is taking for granted that the service will be performed according to the established standards; dimension three, responsiveness, refers to the promptness of response and the ability and willingness to serve; four, security, is the confidence that the client perceives in the organization providing the service; and dimension five, empathy, is when the service is individually tailored to the client's taste.

The creators of the gap model, Zeithaml, Parasuraman, and Berry (1990), explain that the causes of dissatisfaction in service quality can be identified as five deficiencies or discrepancies and explain them as follows:

Deficiency 1. It is the discrepancy between user expectations and the perceptions of managers and refers to when managers are unaware of customer expectations and focus their efforts in other directions.

Deficiency 2. It is the discrepancy between management's perceptions and specifications or quality standards, arises when managers are aware of customer expectations, but due to certain circumstances, cannot land them in standardized processes within the organization. 
Deficiency 3. The discrepancy between quality specifications and service delivery, this gap arises when, despite process specifications being aligned with client expectations, the staff providing the service to the client is not trained and does not have the resources to perform the service as required.

Deficiency 4. The difference between service delivery and external communication, the discrepancy occurs when the promises of those responsible for delivering the advertising to the clients exceed the actual service perceived by the client.

Deficiency 5. Also known as the overall deficiency, it refers to the difference between customers' expectations and their perceptions of the service received.

In sum, Zeithaml and Bitner (2002), explain that the main focus of this model is the discrepancy between customer expectations and their perceptions, but to close this gap, the model proposes that the first four deficiencies described above, which are known as the service provider gaps, must be closed. As a result of the above, it can be stated that the internal discrepancies of the service producer are the causes of the negative difference between the client's expectations and his or her perception, which causes his or her dissatisfaction and in turn, leads to poor service quality.

\section{Method}

The subject is a public institution in the state of Sonora, which provides undergraduate and graduate-level education, the purpose of this research is to measure the quality of educational service from the point of view of the students of the career an educational program. Therefore, the population is the students enrolled in that degree in the January-May 2018 semester; the number of students on campus is 263 .

The sample will be non-probabilistic by quota, as explained by Hernández at al. (2014), the sample by quota is commonly used in opinion studies, quotas are formed based on the proportion of some variable of the population; for this study, it is vital to be able to identify if the perception of the quality of the service is different according to the semester that the student is taking, that is why the groups are divided by semester.
For the moment of the development of the investigation the following semesters are counted: second, fourth, sixth and eighth and higher. Therefore, the sampling will be stratified proportionately; it was determined by calculating the proportion of each group in relation to the total population. Subsequently, this proportion of each group is multiplied by the sample size, and with this, the sample size is obtained. The results are shown in Table 1.

\begin{tabular}{|l|r|r|r|}
\hline \multicolumn{1}{|c}{ Group } & \multicolumn{1}{c}{$\begin{array}{c}\text { Number of } \\
\text { students }\end{array}$} & Proportion & \multicolumn{1}{c|}{$\begin{array}{c}\text { Sample } \\
\text { size }\end{array}$} \\
\hline Second semester & 61 & $23.19 \%$ & 36 \\
\hline Fourth semester & 70 & $26.62 \%$ & 42 \\
\hline Sixth semester & 62 & $23.57 \%$ & 37 \\
\hline $\begin{array}{l}\text { Eighth and } \\
\text { largest semester }\end{array}$ & 70 & $26.62 \%$ & 41 \\
\hline Totals & 263 & $100.00 \%$ & 156 \\
\hline
\end{tabular}

Table 1 Sample stratification

Source: Prepared by the authors

The instrument used to evaluate the quality of the service will be the questionnaire developed by Mejías (2005) made up of 22 multiple choice and statement evaluation reagents using the Likert scale that is between one and seven, which was called SERVQUALing. Likewise, we include a section in which the respondent assigns one hundred points among the five dimensions. Also, we include another section of complementary questions.

In this research, twenty-two items are established and classified into five dimensions, which are Tangible Aspects, Reliability, Responsiveness, Security, Empathy.

\section{Procedure}

Firstly, the variables that were studied were determined, and the instrument to collect information was established. For this reason, we used the questionnaire already tested by Mejías (2005), generated in his proposal of the SERVQUALing model. Subsequently, we determined the population to which the study is directed, we calculated the sample size and stratified to observe the particular behaviours of the different identified population groups. The next step was the application of the instrument to the sample; the surveys will be sent to the students via email. 
With the application of Google Forms, the answers will be automatically received at the source email address. The next step is to present the results obtained, exposing them in the breakdown; the discussion and comments of the results will continue, and at the end of this step we will interpret the results, comparing them with the results of other studies similar to it.

\section{Dimensions that students consider most important when evaluating service quality}

As can be seen in table 2, most second semester students consider the dimensions of tangible aspects and reliability important; regular, the dimension of responsiveness; unimportant, the dimension of security; and unimportant, the dimension of empathy. The majority of fourth, sixth and eighth semester students consider the tangible aspects dimension to be significant, the reliability dimension to be necessary, the response capacity dimension to be regular, the security dimension to be unimportant and the empathy dimension to be unimportant.

Overall, $43 \%$ of students consider very importantly the number one characteristic, the appearance of physical facilities, equipment, personnel and communication material used by a Higher Education Institution, which corresponds to the dimension of tangible aspects. $39 \%$ of the students consider important the number two characteristic, the ability of a Higher Education Institution to perform the promised service in a safe and precise manner, which corresponds to the dimension of reliability.

Similarly, $47 \%$ of the students consider the number three characteristic, the willingness of a Higher Education Institution to help customers and give them a fast service, to be regular, which corresponds to the responsiveness dimension. Likewise, $34 \%$ of the students consider unimportant the characteristic of number four, knowledge and friendly treatment of the employees of an Educational Institution of Higher Level and their ability to transmit a feeling of faith and confidence, which corresponds to the dimension of security. And finally, $53 \%$ of the students consider unimportant the number five characteristic, care, individualized attention that an Educational Institution of Superior Level gives to its clients, which corresponds to the dimension of empathy.

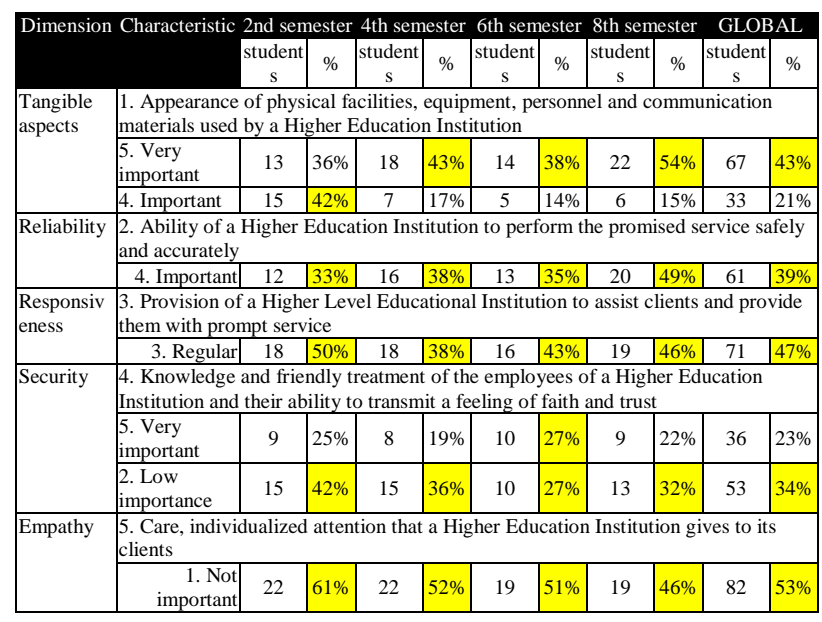

Table 2 Ranking of the importance of the characteristics of the service, from the student's point of view. Highest values obtained

Source. Prepared by the authors

\section{Validation of the classification of the importance of dimensions}

To validate the information obtained in the question about the importance that students attribute to the characteristics, three additional questions are applied. In the first question, it is asked which of the five characteristics is the most important, in the second question, which is the second most important, and in the last question, which is the least important characteristic. The results of these three questions are shown in Table 5.

\begin{tabular}{|c|c|c|c|c|c|c|c|c|c|c|}
\hline Dimensio & 2nd sen & nester & 4th sem & nester & 6th ser & nester & 8th ser & nester & GLO & BAL \\
\hline $\mathbf{n}$ & students & $\%$ & students & $\%$ & students & $\%$ & students & $\%$ & students & $\%$ \\
\hline $\begin{array}{l}\text { Tangible } \\
\text { aspects }\end{array}$ & 8 & $22 \%$ & 16 & $38 \%$ & 13 & $35 \%$ & 19 & $46 \%$ & 56 & $36 \%$ \\
\hline Security & 12 & $33 \%$ & 15 & $36 \%$ & 9 & $24 \%$ & 8 & $20 \%$ & 44 & $28 \%$ \\
\hline \begin{tabular}{|l|} 
Tangible \\
aspects
\end{tabular} & 10 & $28 \%$ & 9 & $21 \%$ & 4 & $11 \%$ & 6 & $15 \%$ & 29 & $19 \%$ \\
\hline $\begin{array}{l}\text { Reliabilit } \\
\text { y }\end{array}$ & 7 & $19 \%$ & 14 & $33 \%$ & 11 & $30 \%$ & 11 & $27 \%$ & 43 & $28 \%$ \\
\hline Security & 5 & $14 \%$ & 8 & $19 \%$ & 12 & $32 \%$ & 13 & $32 \%$ & 38 & $24 \%$ \\
\hline $\begin{array}{l}\text { Tangible } \\
\text { aspects }\end{array}$ & 11 & $31 \%$ & 11.00 & $26 \%$ & 7 & $19 \%$ & 4 & $10 \%$ & 33 & $21 \%$ \\
\hline Empathy & 9 & $25 \%$ & 6.00 & $14 \%$ & 19 & $51 \%$ & 15 & $37 \%$ & 49 & $31 \%$ \\
\hline
\end{tabular}

Table 3 Validation of the importance of the characteristics of the service, from the student's point of view. Highest values obtained

Source: Prepared by the authors

As can be seen in Table 3, the group of second semester students specify that characteristic number four, knowledge and friendly treatment of the employees of an Educational Institution of Higher Level and their ability to transmit a feeling of faith and confidence, is the most important. In contrast, the fourth, sixth and eighth-semester groups indicate that the most essential characteristic is the number one, appearance of the physical facilities, equipment, personnel and communication material used by an Institution of Higher Education.

LIMON-VALENCIA, Luis Alberto, GRIJALVA-TAPIA, Juan, RUIZCASTRO, Manuela and HINOJOSA-TAOMORI, Karina Alejandra. Analysis of the Perception of Quality in Service in a Higher Education Institution with the use of the ModelServQual. Journal-Mathematical and Quantitative Methods. 2019 
And seen globally, with $36 \%$, the most important characteristic is number one. Therefore, confirming the result obtained in the previous section, students consider as the most essential characteristic the tangible aspects, that is, the appearance of the physical facilities, equipment, personnel and communication material used by a Higher Education Institution.

On the characteristic as the second most important, the second-semester students selected the dimension of tangible aspects.

The fourth and sixth-semester students chose dimension number four, security, which refers to knowledge and friendly treatment of the employees of an Educational Institution of Higher Level and their ability to transmit a feeling of faith and confidence. The eighthsemester students determined that the second most important characteristic is number two, the ability of a Higher Education Institution to perform the promised service safely and accurately. Overall, the second most important characteristic is number two, the ability of an Institution of Higher Education to perform the promised service safely and accurately. Therefore, the result achieved in the previous section, where the reliability dimension is in second place, is also confirmed.

Concerning the less critical characteristic, the second and fourth-semester students chose the characteristic of appearance of the physical facilities, equipment, personnel and communication material used by an Educational Institution of Higher Level, on the contrary, the sixth and eighth-semester students chose the characteristic that corresponds to the empathy, care, individualized attention that an Educational Institution of Higher Level gives to its clients.

Overall, empathy was selected as the least important characteristic. With them, in the same way, the result obtained in the question about the classification of importance is confirmed, where empathy, that refers to the care, individualized attention that an Educational Institution of Superior Level gives to its clients, is catalogued as nothing important.
Considering the groups in which the sample under study was segmented, the rating given to the service from lowest to highest is as follows: eighth semester 4.88, good; sixth semester 5.11, good; second semester 5.36, very good; and fourth semester 5.38, very good. In general, students in the Industrial Engineering career, qualify the service of this institution with a score of 5.18, which is equivalent to good. The above can be seen in a graphic in Figure 1.

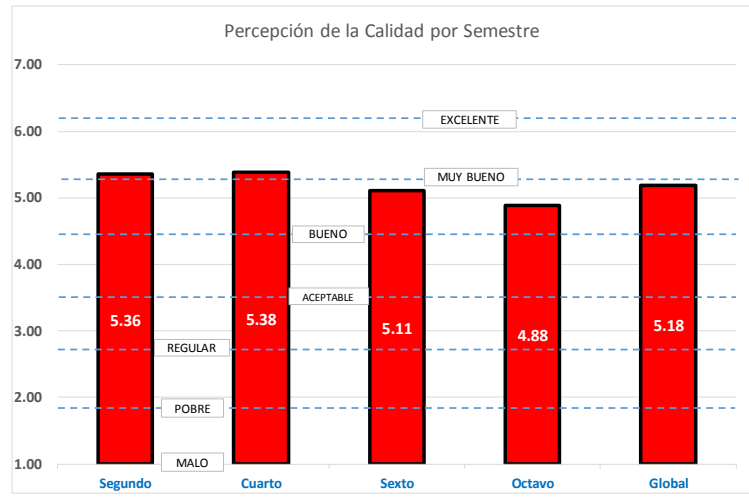

Figure 1 Perception of service quality by semester Source: Prepared by the authors

Similarly, the variable with the fewest points obtained is one: The Institution has modern-looking machinery and equipment, with 3.80 points. On the other hand, the highest points were obtained by variable fifteen: the student feels safe in his transactions with the institution, with 5.72 points, which corresponds to very good.

As a discussion of the results, we highlight three points: First, the order of importance that the students of the major attribute to the characteristics of the service which is the following: as very important they consider dimension one, tangible aspects; as important, dimension two, reliability; as regular, dimension three, response capacity; as not very important, dimension four, security; and not important, dimension five, empathy. This classification of the importance of service characteristics refers to customer expectations, as presented in the theoretical framework.

Secondly, we present the results of the quality rating: the highest rated dimension is dimension four, security; the second-highest rated is dimension three, responsiveness; the third highest-rated is dimension five, empathy; the fourth highest-rated is dimension two, reliability. 
And the lowest rated is dimension one, intangible aspects. If we place this point with those seen in the theoretical framework, this rating refers to the customer's perception of the service he receives. These results can be seen in Table 4.

\begin{tabular}{|c|l|l|l|c|c|}
\hline & \multicolumn{1}{c|}{ Dimension } & \multicolumn{1}{c}{ Feature } & Expectation & Perception & Rating \\
\hline 1 & $\begin{array}{l}\text { Tangible } \\
\text { aspects }\end{array}$ & $\begin{array}{l}\text { 1. Appearance of } \\
\text { the facilities }\end{array}$ & $\begin{array}{l}\text { 5. Very } \\
\text { important }\end{array}$ & 4.59 & Good \\
\hline 2 & Reliability & $\begin{array}{l}\text { 2. Ability of a } \\
\text { Higher Level } \\
\text { Educational } \\
\text { Institution to } \\
\text { perform the service }\end{array}$ & 4. Important & 5.09 & Good \\
\hline 3 & Responsiveness & $\begin{array}{l}\text { 3. Willingness of } \\
\text { an Institution to } \\
\text { help clients and } \\
\text { give them a fast } \\
\text { service }\end{array}$ & 3. Regular & 5.35 & $\begin{array}{l}\text { Very } \\
\text { Good }\end{array}$ \\
\hline 4 & Security & $\begin{array}{l}\text { 4. Knowledge and } \\
\text { friendly treatment } \\
\text { of the employees } \\
\text { of an institution }\end{array}$ & $\begin{array}{l}\text { 2. Low } \\
\text { importance }\end{array}$ & 5.58 & $\begin{array}{l}\text { Very } \\
\text { Good }\end{array}$ \\
\hline 5 & Empathy & $\begin{array}{l}\text { 5. Care, individual } \\
\text { attention }\end{array}$ & $\begin{array}{l}\text { 1. Not } \\
\text { important }\end{array}$ & 5.29 & Good \\
\hline
\end{tabular}

Table 8 Results of the expectations and perceptions of the students under study

Source: Prepared by the authors

Finally, it is relevant to indicate that the final grade, which students assign to ITESCA's quality of service is 5.18; which is interpreted as good service. If we consider that 7.0 is the maximum score according to the scale used, the percentage obtained is $74 \%$.

\section{References}

Asociación Española para la Calidad. (2017). Modelos de calidad. Recuperado el 22 de Abril de 2017, de AEC Asociación Española para la Calidad: https://www.aec.es/web/guest/centroconocimiento/modelos-de-calidad

Brady, M. K., \& Cronin Jr., J. J. (Julio de 2001). Some New Thoughts on Conceptualizing Perceived Service Quality: A Hierarchical Approach. The Journal of Marketing, 65(3), 3449.

Duque, E. J. (2005). Revisión del concepto de calidad del servicio y sus modelos de medición. INNOVAR revista de ciencias administrativas y sociales, 64-80.

Duque, E. J., \& Chaparro, C. R. (2012). Medición de la percepción de la calidad del servicio de educación por parte de los estudiantes de la UPTC Duitama. Criterio Libre, 10(16), 159-192. Obteined from https://dialnet.unirioja.es/descarga/articulo/396 6855.pdf
Duque, E. J., \& Gómez, Y. D. (2014). Evolución conceptual de los modelos de medición de la percepción de calidad del servicio: una mirada desde la educación superior. Suma de negocios, 5(12), 180-191. Retrieved on September 19, 2017, from http://www.elsevier.es/es-revistasuma-negocios-208-articulo-evolucionconceptual-los-modelos-medicionS2215910X14700400

Duque, O., \& Edison, J. (2005). Revisión del concepto de calidad del servicio y sus modelos de medición. INNOVAR Revista de Ciencias Administrativas y Sociales, 15(25), 64-80. Obteined from http://www.redalyc.org/pdf/818/81802505.pdf

Duque, O., Edison, J., \& Chaparro, C. R. (2012). Medición de la percepción de la calidad del servicio de educación por parte de los estudiantes de la UPTC Duitama. Criterio Libre, 10(16), 159-192. doi:ISSN 1900-0642

Edwards, V. (1991). El concepto de la calidad de la educación. Santiago, Chile: Oficina Regional de Educación de la UNESCO para América Latina y el Caribe.

Fernández, P., \& Bajac, H. (2003). La gestión del marketing de servicios: Principios y aplicaciones para la actividad gerencial. Naucalpan de Juárez, Mexico: Granica México.

Hernández, R., Fernández, C., \& Baptista, M. d. (2014). Metodología de la investigación (6a ed.). Mexico City, Mexico: McGraw-Hill / Interamenticana Editores.

Lovelock, C., Reynoso, J., D’Andrea, G., \& Huete, L. (2004). Administración de servicios: Estrategias de marketing, operaciones y recursos humanos (1a ed.). Naucalpan, Estado de México, Mexico: Pearson Educación de México.

Martin, M. J. (2013). Power hand tool customers' determination of service quality and satisfaction in a repair/return process: A quantitative study. International Academy of Marketing Studies Journal, 20(1), 36-52. Obteined from http://search.proquest.com/docview/143391213 0

LIMON-VALENCIA, Luis Alberto, GRIJALVA-TAPIA, Juan, RUIZCASTRO, Manuela and HINOJOSA-TAOMORI, Karina Alejandra. Analysis of the Perception of Quality in Service in a Higher Education Institution with the use of the ModelServQual. Journal-Mathematical and Quantitative Methods. 2019 
Matsumoto, R. (2014). Desarrollo del Modelo Servqual para la medición de la calidad del servicio en la empresa de publicidad Ayuda Experto. Perspectivas, 34, 181-209.

Mejías, A. A. (Junio de 2005). Modelo para medir la calidad del servicio en los estudios universitarios de postgrado. Scielo Universidad, Ciencia y Tecnología, 9(34), 81-85. Obteined from Scielo: http://www.scielo.org.ve/scielo.php?script=sci_ arttext\&pid=S1316-48212005000200004

Organización Mundial de Comercio. (Marzo de 2017). Servicios: normas encaminadas al crecimiento y la inversión. Obteined from Organización Mundial de Comercio: https://www.wto.org/spanish/thewto_s/whatis_s /tif_s/agrm6_s.htm

Reyes, O., \& Reyes, M. (2012). Percepción de la calidad del servicio de la educación universitaria de alumnos y profesores. Revista Internacional Administración \& Finanzas, 12(12), 87-98. Obteined from https://dialnet.unirioja.es/servlet/articulo?codig o=3991416

Sáez, A. (2011). Factores criticos para la medicion de la calidad de servicio del aseo urbano en el municipio Maracaibo. Revista Telos, 329+. Obteined from http://go.galegroup.com/ps/i.do?p=IFME\&sw= $\mathrm{w} \& \mathrm{u}=\mathrm{pu} \& \mathrm{v}=2.1 \& \mathrm{it}=\mathrm{r} \& \mathrm{id}=\mathrm{GALE} \% 7 \mathrm{CA} 31707$ $5418 \&$ sid $=$ summon $\&$ asid $=\mathrm{d} 7 \mathrm{~d} 7414 \mathrm{~cd} 8 \mathrm{fa} 2 \mathrm{aea} 6$ 7bd6bfbdf0a39b0

Torres, M., \& Vásquez, M. L. (2015). Modelo de evaluación de la calidad: Caracterización y análisis. Revista científica Compendium, 18(35), 57-76. Obteined from http://www.ucla.edu.ve/dac/compendium/revist a35/Compendium_35_2015_4.pdf

UNESCO. (10 de Septiembre de 2017a). Sobre la UNESCO. Obteined from UNESCO: http://es.unesco.org/about-us/introducingunesco

Vargas, M. E., \& Aldana, L. (2006). Calidad y servicio: Conceptos y herramientas (1a ed.). Bogotá, Colombia: Ecoe ediciones.
Zeithaml, V. A., Parasuraman, A., \& Berry, L. L. (1990). Calidad total en la gestión de servicios (1a ed.). Madrid, Spain: Ediciones Díaz de Santos. 